\title{
Nádúr Daonna (Natureza humana): An Intervention to Work with nature in the Intellectual Development of First Year Engineering Students
}

\author{
Domhnall Sheridan \\ Technological University Dublin, domhnall.sheridan@tudublin.ie \\ Michael Carr \\ Technological University Dublin, michael.carr@tudublin.ie
}

Follow this and additional works at: https://arrow.tudublin.ie/schmuldistcon

Part of the Engineering Education Commons, and the Other Engineering Commons

\section{Recommended Citation}

D. Sheridan and M. Carr, "Nádúr Daonna (Natureza humana): An Intervention to Work with nature in the Intellectual Development of First Year Engineering Students," 2018 3rd International Conference of the Portuguese Society for Engineering Education (CISPEE), 2018, pp. 1-4, doi: 10.1109/

CISPEE.2018.8593461.

This Article is brought to you for free and open access by the School of Multidisciplinary Technologies at ARROW@TU Dublin. It has been accepted for inclusion in Conference papers by an authorized administrator of ARROW@TU Dublin. For more information, please contact arrow.admin@tudublin.ie, aisling.coyne@tudublin.ie,gerard.connolly@tudublin.ie.

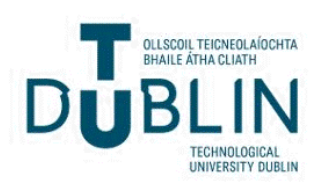




\section{Nádúr Daonna (Natureza humana): An Intervention to Work with nature in the Intellectual Development of First Year Engineering Students}

\author{
Domhnall Sheridan \\ School of Multidisciplinary Technologies \\ Dublin Institute of Technology \\ Dublin, Ireland \\ Domhnall.sheridan@dit.ie
}

\author{
Michael Carr \\ School of Multidisciplinary Technologies \\ Dublin Institute of Technology \\ Dublin, Ireland \\ Michael.carr@dit.ie
}

\begin{abstract}
For most of the 20th Century there has been a debate among psychologists, educationalists and others as to whether nature or nurture determined the personality and capabilities of the adult person. Only in the last decade has an answer been found for that perennial question: the adult is the product of both nature and nurture. The genotype, the genetic inheritance from parents provides a template, but the expression of the genotype, the phenotype, depends on the interaction between the individual and their environment. Nothing is written in stone: the young child beginning education has almost infinite possibilities.
\end{abstract}

In order for this to be realized, the educational system must act so as to maximise the potential in each individual's genotype. This is quite a tall order, and the resources required beyond most governments. There are alternatives to a tailor-made education for every individual, and that is to build upon what is known about the intellectual development of children and young adults and incorporate it into the current, far from perfect system.

This intervention centered on an open-ended design exercise given to first-year Engineering students taking a traditional Physics module to see if it had a measurable effect on their understanding. The results have been modest, but significant. Small interventions do make a difference, and if introduced on a larger scale across all modules on the programme could help students achieve their potential.

The initiative described in this paper was undertaken within a traditional first-year Mechanical Engineering three-year ordinary degree programme at Dublin Institute of Technology (DIT), Ireland. The learning activity required students to analyse an open-ended design problem, re- interpret it in their own words, and then outline and implement a workable solution. In preparation for this exercise, much of the relevant knowledge was encountered earlier in the semester in both the mechanics and physics courses, but not previously integrated in any way, nor applied to a real world problem.

The students' conceptual understanding of the Physics involved in the exercise was tested before and afterwards, and analysed to see if any improvements had occurred. A statistically significant difference was found, validating the efficacy of this intervention, albeit with a small sample.
Keywords—educational psychology, Kahneman, Type I and II thinking, conceptual understanding

\section{INTRODUCTION}

Francis Galton was born in 1822, and was the half-cousin of Charles Darwin. Perhaps inspired by the ideas of Darwin, Galton wrote a book, Hereditary Genius in 1869, in which he gave numerous examples of famous scientists (and others) who were descended from similar minds; talent, he concluded was inherited. Many disagreed; in 1872, a Swiss botanist Alphonse de Candolle, pointed out that great scientists in the previous two centuries had come from countries or cities with religious tolerance, widespread trade links, a moderate climate and democratic governments - suggesting that achievement owed more to circumstance and opportunity than to inherited genius. This was the beginning of a debate that has lasted more than a century, that of nature versus nurture, a term Galton himself coined. This replaced the previous thinking in education, that of men like David Hume and John Stuart Mill that the human mind was a tabula rasa, an empty tablet at birth. [1]

Galton was a brilliant polymath, who in many ways is the founder of statistics, inventing such concepts as correlation and regression. In his study of human nature, he discovered a very important fact, that sample means regress towards the population mean. This implies, for example, that children of two short parents will have average heights than tend towards the mean of the population to which they belong, not the simple mean of the two parents.

Sadly, Galton's work, and that of others, led to the nasty pseudo-science of eugenics in the 20th century, where those of low intelligence were sterilized, lest their bad genes spoil the gene pool. A better example of 20th century science was the investigations of Jean Piaget, the Swiss child psychologist. Piaget studied children almost as a zoologist studies animals, and noted that babies and young children went through clearly defined stages of development, with the child slowly moving from a very concrete worldview to an abstract one. Neurologists add to this that the young child is making neural connections in the brain, building the adult brain connection by connection. Here is where the environment enters: if the young 
child is deprived of food, those neural connections may not be made, and may never be made. [2]

The genes define the blueprint, but the environment must supply the building materials, otherwise the child will not reach its potential. A further recent insight is that genes function like on/off switches. The interaction with the environment switches some genes on and others off. The adult is very much the product of both nature and nurture.

It is surely the task of the educator to use that knowledge to enable each person reach their full potential. It is unlikely, given finite resources, that every individual will receive a personalised education, but there are general steps that can be taken to maximise development.

One such approach is based on the research of the Israeli psychologist Daniel Kahneman, who won the 2002 Nobel Prize for Economics for his work on prospect theory. His bestselling book [3], Thinking Fast and Slow identifies the ways in which the brain works and the types of mistakes to which it is prone.

Along with Shane Fredericks [4], he identifies the two types of cognitive processes in the human brain, those executed quickly with little conscious deliberation and those that are slower and more reflective called "System 1" and "System 2" processes, respectively.

System 1 responses are quick and require almost no mental effort, and were clearly of evolutionary benefit for early humans facing dangers on all sides. System 1 may be quick, but it can be wrong. The more reflective System 2 takes time and is associated with a higher IQ: more intelligent people are more patient. A Cognitive Reflection Test (CRT) that uses three questions designed to provoke a System 1 response that is incorrect, has been used to identify the System 2 people.

It also makes sense in education to stimulate System 2, if even occasionally, as System 1 is unlikely to learn anything long-term. Recent work by Mueller and Oppenheimer [5], The Pen Is Mightier Than the Keyboard suggests that students use System 1 to touch type and so learn very little from a lecture, but when forced to use a pen longhand must try and summarise the lecture, employing System 2, and thereby learning something.

This paper examines one such effort to 'force' students into system 2 thinking, by giving them an open- ended problem, in an area covered the previous semester, with minimum guidance. The students were tested before and after the exercise on their conceptual understanding of the area (the gas laws). The results are encouraging, showing a significant improvement in conceptual understanding between the start and finish of the exercise.

\section{BACKGROUND TO THE GROUP}

The students in this project were first-year level-7 degree students (previously Technician Diploma) on Ireland's Qualification framework, where level-7 is an ordinary degree, level-8 an honours degree, level-9 a masters, and level-10 a doctorate.
The first-year students of Mechanical Engineering in DIT constitute an above average (for level-7 nationally) group of students, with Leaving Certificate entry points typically around 350 (out a maximum possible of 625). In the Academic year 2016-17, the number of students was 60 , with an average of 354 points. It is also worth mentioning the overwhelming male bias of the class, with only five female students on the course in that year.

\section{OPEN DESIGN PROJECT DETAILS}

The exercise, based on a single-session exercise on the Gas Laws, was introduced at the beginning of the second semester, the students having studied the relevant material in the first semester.

The exercise required students to calculate the spring constant needed for an emergency release valve on a gas pressure vessel. The students were broken into groups of three, and were given a short presentation and handout on the problem. They had two hours in the lab, with assistance from two lecturers, and then had to email their solution, in the form of a Word document and an Excel spreadsheet by Friday of the following week. Given the numbers involved, the exercise was run three times, with around 16 students per session.

The exercise was open-ended and students were given the freedom to go into as much detail as they wished within the time provided. The exercise proved to be challenging for many of the students, who were more used to well-defined laboratory work. The good students rose well to the challenge, producing a wide variety of interesting and satisfactory designs that met the brief.

\section{TEST RESULTS}

Students were surveyed at the start and at the end of the exercise. 42 students did the first test and 48 the second. They were asked 5 conceptual questions, such as the ones below:

1. A bubble forms at the bottom of a lake. As it rises to the surface (but before it gets there), will it grow, shrink, or burst? Why?

2. As molecules collide with the surface of a container, they create: $a$. density, $b$. potential energy, $c$. pressure, d. mass.

3. The pressure in car tires is greater at noon than at midnight. True or false?

Conceptual learning is a process by which students learn how to organize information in logical mental structures. Conceptual learning focuses on learning organizing principles - the cubby holes in which the mind organizes facts into ideas. Conceptual learning is a catalyst for challenging students to think at more advanced levels. Generally, students perform poorly on conceptual tests, even when they display competence in traditional testing.

The maximum marks for the questions was 35. Over the two sessions, the results were: 
TABLE I.

\begin{tabular}{|c|c|c|}
\hline 2017 & \multicolumn{2}{|c|}{ Results } \\
\hline \multicolumn{3}{|c|}{ Start of Session 1} \\
\hline & $\mathrm{n}$ & 42 \\
\hline & Mean & 20.61 \\
\hline & Standard Deviation & 8.51 \\
\hline \multicolumn{3}{|c|}{ End of Session 2} \\
\hline & $\mathrm{n}$ & 48 \\
\hline & Mean & 23.98 \\
\hline & Standard Deviation & 6.89 \\
\hline \multicolumn{3}{|c|}{ Statistical Analysis } \\
\hline & Difference & 3.370 \\
\hline & Standard error & 1.618 \\
\hline & $\%$ Confidence Interval & 0.1542 to 6.5858 \\
\hline & t-statistic & 2.083 \\
\hline & DF & 88 \\
\hline & Significance level & $\mathrm{p}=0.0402$ \\
\hline \multicolumn{3}{|c|}{ Student t-test } \\
\hline & $\mathrm{n}$ & 41 \\
\hline & Significance level & 0.01 \\
\hline \multicolumn{3}{|c|}{ One tail test } \\
\hline & t-value & -2.54311 \\
\hline & p-value & 0.006457 \\
\hline & Cohen-d & 0.427056 \\
\hline
\end{tabular}

There is a significant difference $(p=0.0402)$ between the students' conceptual understanding at the end of the exercise than at the beginning, in other words, the null hypothesis, that the two means are similar, is rejected at the 95\% Confidence Interval. It is difficult to generalize this finding, as the numbers involved are relatively small.

The student t-test was devised by William Gosset, a statistician at Guiness's brewery in Dublin in 1908. Results for the 41 pairs involved showed similar results, i.e. at a $1 \%$ Confidence Interval and a one-tailed test, the result was significant, with a p-value of 0.006457.

Cohen's effect test was also calculated; this is determined by calculating the mean difference between the two groups, and then dividing the result by the pooled standard deviation. The result for this, 0.427056 , is more than halfway between a medium effect $(0.3)$ and a large effect $(0.5)$.

Further work is needed to see if this learning effect lasts, perhaps after 6 weeks.

\section{ACKNOWLEDGMENT}

The authors wish to thank Louis Bucciarelli, Emeritus Professor of Engineering and Technology Studies at the Massachusetts Institute of Technology, Cambridge, USA, who first introduced open-ended design problems to our students during his time at DIT in 2009, as a Fulbright scholar, and also Ference Marton, of the University of Gothenburg, Sweden, who gave very valuable guidance on the first iteration of this project during REES 2015 in Dublin. It was Professor Marton's advice to switch from standard gas law questions before and after the exercise to conceptual ones.

\section{CONCLUSIONS}

Transforming engineering education is not a simple enterprise. For starters, those who teach in engineering schools are engineers first and educators second. They tend to teach as they were taught, and are unfamiliar with research in education, understandably preferring to concentrate their limited research resources on their core discipline.

And why should one change one's mind in the absence of crisis? As John Kenneth Gailbraith [6] said, "Faced with the choice between changing one's mind and proving that there is no need to do so, almost everyone gets busy on the proof."

Any change needs to be grounded in research, but practitioners must be made aware of that research. Educationalists must be familiar with the current theories of how the brain works, so that teaching can stimulate the System 2 brain, not just the System 1.

The modest project described in this paper does, we believe, stimulate the System 2 response and also creates a sense of unease in the students that leads them to look outside their comfort zone (or standard learning paradigm). It is not a panacea: teaching that focuses exclusively on System 2, will, as Kahneman points out, tire out students and lead to fatigue rather than education. This is perhaps a warning for courses based heavily on problem based learning (PBL).

But such simple projects, sprinkled in more traditional modules can be effective, as shown by the clear improvement in students' scores on conceptual questions, whilst being acceptable within the overall traditional learning paradigm of the majority of the faculty. It is difficult to persuade an entire faculty to change teaching methods to Problem Based Learning or active learning, but this intervention shows that the individual teacher, within a traditional engineering programme, can make a difference with modest inputs that do not involve wholescale re-writing of the syllabus.

The lesson for educators is much the same as for psychologists and geneticists: education requires both traditional methods and newer more active learning modes in order to fully develop the student's potential. It is not nature or nurture, but both. It is not traditional versus modern, but both.

\section{REFERENCES}

[1] [Ridley, Matt, Nature via Nurture, 4th Estate, London, 2003, Chapter 3. [2] ibid., Chapter 5. 
[3] Kahneman, Daniel, Thinking Fast and Slow, Farrar, Straus and Giroux, 2011.

[4] Fredericks, Shane, Cognitive Reflection and Decision Making, Journal of Economic Perspectives - Volume 19, Number 4-Fall 2005-Pages 25-42.

[5] Mueller and Oppenheimer, The Pen Is Mightier Than the Keyboard, Psychological Science June 2014 vol. 25 no. 6 1159-1168.

[6] Gailbraith, John Kenneth, Economics, Peace and Laughter (1971), p. 50 